\title{
Platelet Isoforms of Platelet-derived Growth Factor Stimulate Fibroblasts To Contract Collagen Matrices
}

\author{
Richard A. F. Clark, ${ }^{\star}$ Joy M. Folkvord, ${ }^{\star}$ Charles E. Hart, ${ }^{\ddagger}$ Mark J. Murray, ${ }^{\ddagger}$ and John M. McPherson ${ }^{5}$ \\ ${ }^{*}$ Department of Medicine, National Jewish Center for Immunology and Respiratory Medicine, Denver, Colorado 80206; ${ }^{8}$ Connective \\ Tissue Research Laboratories, Collagen Corporation, Palo Alto, California 94303; and ${ }^{\ddagger}$ ZymoGenetics, Seattle, Washington 98105
}

\begin{abstract}
Fibroplasia and angiogenesis are essential components of tissue repair when substantial tissue has been lost at a site of injury. Platelets and monocyte/macrophages accumulate at these sites and release a variety of growth factors that are thought to initiate and sustain the repair. Often the involved tissue contracts, a process that can markedly reduce the amount of fibroplasia and angiogenesis necessary for the reestablishment of organ integrity. Such tissue contraction occurs over hours or days, a much slower time course than the rapid, reversible contraction of muscle tissue. Fibroblasts, which are rich in f-actin bundles, appear to be responsible for wound contraction. However, the signals that stimulate contraction are not known. Using cultured fibroblasts, which are also rich in f-actin bundles, we demonstrate the platelet and monocyte isoforms of platelet-derived growth factor (PDGF; AB and BB) but not PDGF-AA, can stimulate fibroblasts to contract collagen matrix in a time course similar to that of wound contraction. In addition, PDGF appears to be the predominant fibroblast/collagen gel contraction activity released from platelets. Vasoactive agonists known to stimulate smooth and striated muscle contraction do not stimulate fibroblast-driven collagen gel contraction.
\end{abstract}

\section{Introduction}

When substantial tissue loss occurs after injury, fibroblast ingrowth, connective tissue deposition, and angiogenesis, often in concert with tissue contraction, reestablish organ integrity $(1,2)$. Using explants from 1-2-wk wounds, Gabbiani et al. (3) demonstrated that ex vivo granulation tissue contraction was actin dependent. The actin-rich cells in wound tissue have been characterized as specialized fibroblasts called myofibroblasts (4). This same fibroblast phenotype has been observed in tissue taken from patients with a variety of fibrocontractive diseases (2). Thus, f-actin-rich fibroblasts may also be responsible for the very slow, progressive tissue contraction observed in scleroderma, constrictive pericarditis and myocarditis, pulmonary fibrosis, and liver cirrhosis.

Address correspondence to Dr. Richard A. F. Clark, Department of Medicine, National Jewish Center for Immunology and Respiratory Medicine, Denver, CO 80206.

Received for publication 12 May 1989.

J. Clin. Invest.

(C) The American Society for Clinical Investigation, Inc.

0021-9738/89/09/1036/05 \$2.00

Volume 84, September 1989, 1036-1040
The so-called myofibroblast contains large f-actin bundles that course longitudinally along the cytoplasmic face of the plasma membrane in the direction of the major cell axis. In wounds the intracellular actin bundles are aligned with extracellular fibronectin fibrils across the radial axis of the wound. These networks of intra- and extracellular microfilaments may be responsible for transmitting the collective force generated by fibroblasts across the tissue (5). Although the biomechanics by which this type of tissue contraction may occur have been investigated, little is known about the signals that stimulate such contraction. Platelet-derived growth factor (PDGF)-BB ${ }^{1}$ and $-\mathrm{AB}$ are presumed to be released from platelets and monocyte/macrophages at sites of tissue injury (1). Since PDGF is known to stimulate fibroblast migration $(6,7)$ and proliferation (8), and arterial smooth muscle contraction (9), we investigated the ability of PDGF to initiate fibroblast contraction of collagen matrix.

Cultured fibroblasts mixed with soluble collagen, which is then allowed to gel, contract the collagen matrix over the course of several days when serum is added to the culture (10). Like granulation tissue contraction, fibroblast-driven collagen gel contraction is actin dependent (10). In addition, fibronectin-containing microfibrils interconnect cultured fibroblasts (11) and are aligned with intracellular f-actin bundles (12). Because of the similarities between the in vitro system and contracting wound tissue, Bell et al. have proposed that fibroblast-contracted collagen gels represent a tissue-equivalent construct $(10,13)$. Therefore, we have used this system to test whether PDGF can stimulate fibroblast-driven connective tissue contraction.

\section{Methods}

Fibroblast/collagen gel contraction assay. Human fibroblasts isolated from minced, collagenase-treated foreskin dermis were grown to a population-doubling level of 6-12 in Eagle's MEM and 10\% fetal bovine serum. The cells were harvested with trypsin and EDTA, washed, and mixed with reconstituted fibrillar collagen (14) in Eagle's MEM and appropriate experimental conditions. The final concentrations of collagen and cells were $4 \mathrm{mg} / \mathrm{ml}$ and $1 \times 10^{6}$ fibroblasts $/ \mathrm{ml}$, respectively. $0.5-\mathrm{ml}$ volumes of the mixture were plated into $16-\mathrm{mm}$-diam, flat-bottom bacteriologic plastic wells precoated with $20 \mathrm{mg} / \mathrm{ml}$ of BSA. The collagen/cell mixtures were incubated in humidified air at $37^{\circ} \mathrm{C}$ and gelled within $30 \mathrm{~min}$. At $1,2,3,4,5$, and $24 \mathrm{~h}$ after plating the major and minor axes of each gel were measured and the average diameter converted to area.

1. Abbreviations used in this paper: EGF, epidermal growth factor; FGF, fibroblast growth factor; PDGF, platelet-derived growth factor; TGF-beta, tumor necrosis factor beta. 
Initially, we monitored gel contraction both by calculating gel areas from gel diameters and by determining gel volume from fluid displacement. In our system, both area and volume determinations gave essentially the same results. Therefore, we have chosen, as have other investigators $(10,15,16)$, to follow reduction in gel area. In addition, we have confirmed that the degree of fibroblast-driven collagen gel contraction is positively correlated with the number of fibroblasts added to the collagen and inversely proportional to the collagen concentration as previously reported by Bell et al. (10).

Hoechst dye assay for DNA. Proliferation of fibroblasts in collagen gels was monitored by a modified Hoechst dye fluorescence assay for DNA (17). Aliquots of sonicated fibroblasts and collagen gel were diluted 10-fold in a pH 7.4 buffer containing $10 \mathrm{mM} \mathrm{NaH}_{2} \mathrm{PO}_{4}, 4 \mathrm{M}$ $\mathrm{NaCl}$, and $2 \mathrm{mM}$ EDTA. The suspension was vortexed vigorously and clarified by centrifugation at $9,500 \mathrm{~g}$ for $5 \mathrm{~min}$ in a microfuge (model B; Beckman Instruments, Inc., Palo Alto, CA). No detectable DNA was observed in the pellet. The centrifugation removed most of the collagen gel material from cell extracts. Conditions were adjusted so that the supernatant contained $\sim 100 \mathrm{ng}$ DNA $\left(\sim 1 \times 10^{4}\right.$ cells $)$ per 100-250 $\mu$ l. Replicate aliquots of the supernatant were diluted to a final volume of $1 \mathrm{ml}$ in the same phosphate buffer containing $2 \mathrm{M}$ $\mathrm{NaCl}$. Hoechst dye 22358 (Sigma Chemical Co., St. Louis, MO) was added to a final concentration of $0.175 \mu \mathrm{g} / \mathrm{ml}$ from a concentrated stock in water. Salmon sperm DNA (Calbiochem-Behring Corp., San Diego, CA) was diluted in the same buffer system and used as a standard in the range of $0-250 \mathrm{ng}$. Fluorescence was measured in a fluorescence spectrophotometer (Perkin-Elmer Corp., Norwalk, CT) set at $365 \mathrm{~nm}$ excitation and $458 \mathrm{~nm}$ emission. Collagen gels containing no cells gave little or no background. Furthermore, collagen gels did not interfere with DNA measurement of the salmon sperm DNA standard.

$\left[{ }^{3} H\right]$ Thymidine uptake. Neonatal foreskin fibroblasts were plated at 12,500 cells $/ \mathrm{cm}^{2}$ in DME with $25 \mathrm{mM}$ Hepes, $100 \mathrm{U} / \mathrm{ml}$ penicillin, $100 \mu \mathrm{g} / \mathrm{ml}$ streptomycin, and $0.4 \%$ FCS and incubated $3 \mathrm{~d}$ to obtain quiescence. Then the various PDGF isoforms were added and cultures were incubated for an additional $24 \mathrm{~h}$. The next day cultures received $20 \mu \mathrm{l}$ of HBSS containing $1 \mu \mathrm{Ci}$ methyl- $\left[{ }^{3} \mathrm{H}\right]$ thymidine and were incubated $4 \mathrm{~h}$. Subsequently, the medium was replaced with $200 \mu \mathrm{l}$ DME containing $3 \mathrm{pM}$ cold thymidine to displace unincorporated $\left[{ }^{3} \mathrm{H}\right]$ thymidine. After $1 \mathrm{~h}$, medium was removed and the DNA precipitated with $200 \mu \mathrm{l}$ ice-cold $10 \%$ TCA. Precipitated DNA was resuspended with $0.2 \mathrm{~N} \mathrm{NaOH}$ containing $40 \mu \mathrm{g} / \mathrm{ml}$ carrier DNA and incorporated tritium quantified in a scintillation counter.

$P D G F$. PDGF from human platelets was obtained from $\mathrm{R} \& \mathrm{D}$ Systems (Minneapolis, MN). Isolated PDGF was $>99 \%$ pure and consisted of 85\% PDGF-AB and 15\% PDGF-BB as judged by ELISA (18). Recombinant DNA-derived PDGF-AA and -BB were isolated from a yeast expression system (18).

\section{Results}

When PDGF, isolated from human platelets, was added to the fibroblast-collagen matrix system, increasing gel contraction occurred with increasing doses of PDGF. Of note, contraction always began within 2-3 $\mathrm{h}$ after the addition of PDGF. Collagen gels containing fibroblasts, but no PDGF, contracted little by $24 \mathrm{~h}$ and never contracted within the first $5 \mathrm{~h}$. Collagen gels without cells did not contract with any dose of PDGF (data not shown). PDGF-stimulated gel contraction was not secondary to increasing cell numbers since fibroblasts within the collagen gel did not proliferate during the $24-\mathrm{h}$ contraction period nor during a subsequent $3-d$ period as judged by a Hoechst dye assay for DNA (see Methods).

Since PDGF isolated from human platelets consists of 85-90\% PDGF-AB and 10-15\% PDGF-BB isoforms (Hart, C. E., unpublished observations), we examined the activity of recombinant PDGF-BB and -AA isoforms. PDGF-BB, but not
-AA, stimulated fibroblast-driven collagen gel contraction (Fig. 1 B). To document that all PDGF preparations used in this study were biologically active, we measured $\left[{ }^{3} \mathrm{H}\right]$ thymidine incorporation of fibroblasts plated on tissue culture plastic dishes and incubated $24 \mathrm{~h}$ in the presence of the various PDGF isoforms (see Methods). All PDGF isoform preparations stimulated DNA synthesis in a dose-response profile (Fig. 2) similar to that recently reported by Raines et al. (19).

To determine whether other factors released from platelets could stimulate fibroblast-driven collagen gel contraction, platelets were isolated from plasma by centrifugation at $900 \mathrm{~g}$ for $10 \mathrm{~min}$ (20). Washed platelets were resuspended in $20 \mathrm{mM}$ Tris, $145 \mathrm{mM} \mathrm{NaCl}, 5 \mathrm{mM} \mathrm{KCl}, 5 \mathrm{mM}$ glucose, $2.5 \mathrm{mM}$ EDTA, pH 7.5, at a volume of $5 \mathrm{ml}$ /original unit of platelets. They were stimulated to release their products with $7 \mathrm{U} / \mathrm{ml}$ thrombin at room temperature. After $15 \mathrm{~min}$ platelets were centrifuged at $22,000 \mathrm{~g}$ for $20 \mathrm{~min}$ at $4^{\circ} \mathrm{C}$ and the supernatant containing the released platelet products (platelet releasate) was collected and stored at $-20^{\circ} \mathrm{C}$ until used. Protein concentration of platelet releasate was determined by the Lowry technique (21). Fig. $3 \mathrm{~A}$ demonstrates that increasing amounts of the platelet-released protein stimulated increasing degrees of fibroblast-driven gel contraction.

The question remained, however, whether PDGF was the only active factor in platelet releasate. To examine this question we constructed an anti-PDGF antibody affinity column. The MAb 121.6.1.1.1 (22), which recognizes both the PDGF$\mathrm{AB}$ heterodimer and PDGF-BB homodimer isoforms, was
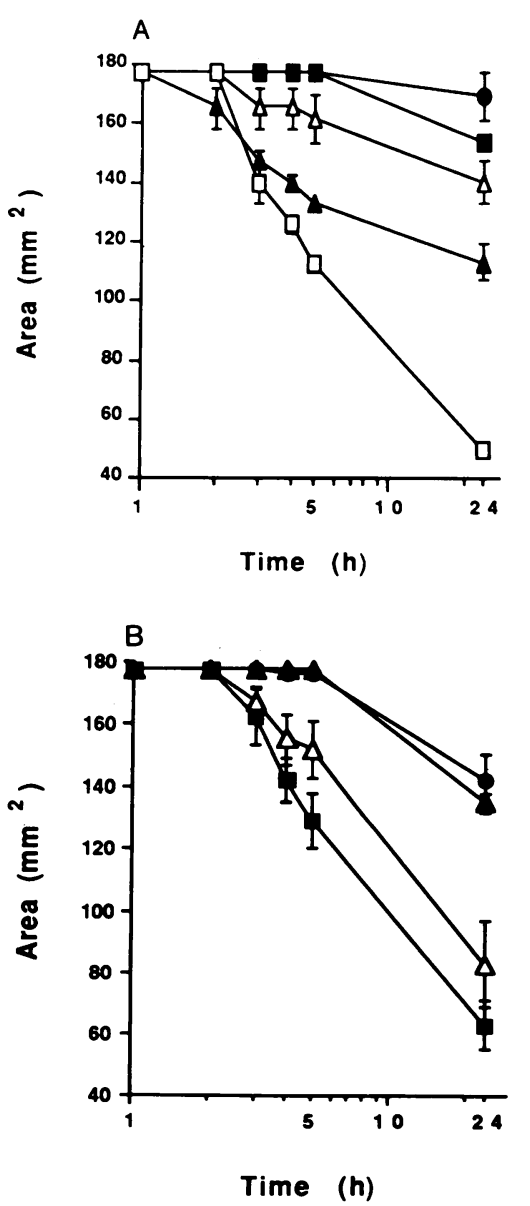

Figure 1. PDGF-AB and -BB, but not -AA, stimulate fibroblastdriven contraction of collagen gels. $(A)$ The representative response of gel contraction to platelet-isolated PDGF at $0(\bullet), 1(\bullet), 3(\Delta), 10$ $(\triangle)$, and $30 \mathrm{ng} / \mathrm{ml}$ (口). (B) Comparison of the PDGF isoforms at 30 ng/ml: PDGF-AA ( $\Delta$ ), PDGF-BB ( $\triangle$ ), PDGF$\mathrm{AB}(\boldsymbol{a})$, and medium alone (๑). Each point with brackets represents the mean \pm SEM of three replicates. Points without brackets indicate that no difference occurred among triplicates. 


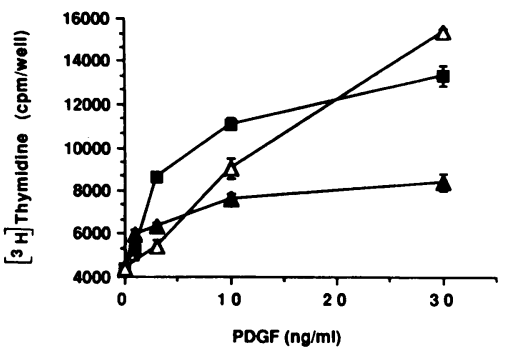

Figure 2. All PDGF isoforms stimulate DNA synthesis of fibroblasts plated on plastic tissue culture dishes: PDGFAA ( $\triangle$ ), PDGF-AB (घ), and PDGF-BB $(\triangle)$. A $10 \%$ serum control gave $18,000 \mathrm{cpm} /$ well. Each point with brackets represents the mean \pm SEM

of three replicates. Points without error bars indicate that no difference occurred among triplicates.

conjugated to $\mathrm{CNBr}$-activated Sepharose beads ( $\mathrm{CNBr}$ Sepharose 4B; Pharmacia Inc., Uppsala, Sweden). Platelet releasates after passage over the anti-PDGF affinity column had PDGF levels $\sim 10 \%$ those of nondepleted releasates as judged by radioreceptor assay (23). As shown in Fig. $3 \mathrm{~B}$, PDGF-depleted releasate failed to stimulate contraction. In contrast, when platelet releasates were passed over a nonimmune IgG affinity column (sham depletion), the activity that stimulated gel contraction was not removed. When PDGF was eluted from the anti-PDGF affinity column and added back to PDGF-depleted platelet releasates to a final concentration of the original releasate $(30 \mathrm{ng} / \mathrm{ml})$, the contractile activity was restored (Fig. $3 \mathrm{~B}$ ). Thus, PDGF appeared to be the major factor in platelet releasates that stimulated fibroblast-driven collagen gel contraction.

Growth factors and cytokines are known to induce other
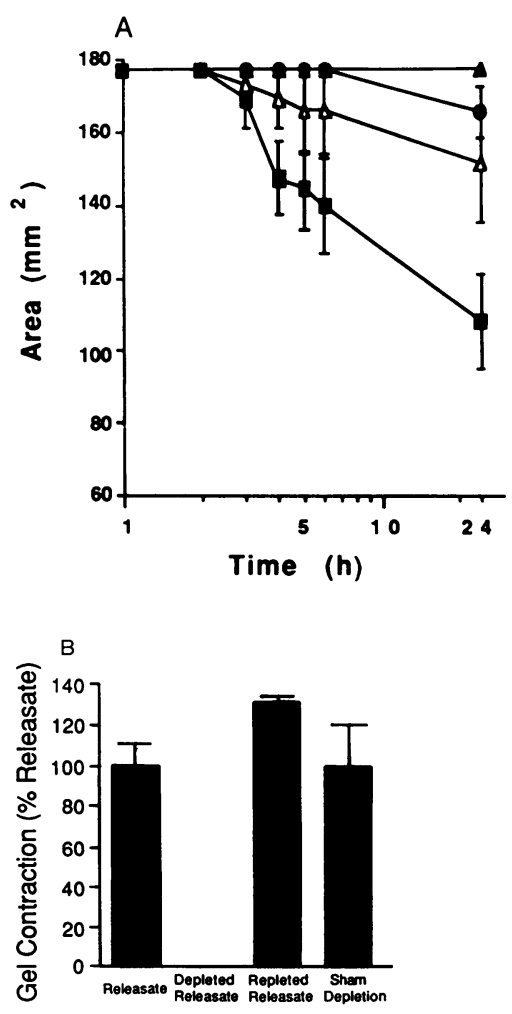

Figure 3. PDGF is the predominant platelet factor that stimulates fibroblast-driven collagen gel contraction. Experiments were performed as described in Methods. $(A)$ The platelet releasate dose response of gel contraction to $3 \mu \mathrm{g} / \mathrm{ml}$ platelet releasate protein $(\Delta), 10$ $\mu \mathrm{g} / \mathrm{ml}$ protein $(\triangle), 30$ $\mu \mathrm{g} / \mathrm{ml}$ protein $(\boldsymbol{\omega})$, and medium alone $(\bullet) .(B)$ The effect of PDGF depletion and repletion from platelet releasates on gel contraction at 4 $h$ as compared with normal releasate containing $30 \mu \mathrm{g} / \mathrm{ml}$ protein and $30 \mathrm{ng} / \mathrm{ml}$ PDGF. Depleted releasate contained $30 \mu \mathrm{g} / \mathrm{ml}$ protein and $3 \mathrm{ng} / \mathrm{ml}$ PDGF. Repleted and sham-depleted releasate contained the same amount of protein and

PDGF as normal releasate. Each bar represents the mean \pm SEM of three replicates. The absence of a bar in the depleted releasate column indicates that the three replicate gels receiving the depleted releasate showed no contraction at $4 \mathrm{~h}$. growth factors and cytokines which may subsequently accumulate in cell culture $(19,24-26)$. Therefore, we have presented our gel contraction data in a log time scale to emphasize the first $5 \mathrm{~h}$ after addition of a test substance to minimize such cascade events. The recent finding that transforming growth factor beta (TGF-beta) stimulated fibroblast contraction of collagen gels after a 24-h delay (27) underscores the importance of potential sequential events. That is, the delayed response may be related to the ability of TGF-beta to induce PDGF mRNA and protein synthesis (24). As shown in Table I, little or no collagen contraction was observed with 10 or 30 ng/ml TGF-beta (Collagen Corp., Palo Alto, CA) (28) at 4 or $24 \mathrm{~h}$ after addition to our system. On the other hand, a $45 \pm 5.0 \%$ decrease in gel area was observed at $48 \mathrm{~h}$ with 30 $\mathrm{ng} / \mathrm{ml}$ TGF-beta. In addition to TGF-beta, we have examined other growth factors and autacoids for their ability to stimulate fibroblast-driven gel contraction (Table I). Fibroblast growth factor (FGF; kindly provided by Dan Rifkin, New York University Medical Center) (29), epidermal growth factor (EGF; Collaborative Research Inc., Lexington, MA), and platelet-associated autacoids stimulated little or no contraction by $24 \mathrm{~h}$.

\section{Discussion}

We demonstrated in this report that fibroblast-driven collagen gel contraction is stimulated by the platelet isoforms of PDGF (AB and BB) but not by PDGF-AA. Furthermore, the fibroblast/gel contraction response to PDGF was separable from PDGF stimulation of fibroblast proliferation. Since fibroblastdriven contraction of collagen gels has been demonstrated to be actin dependent (10), the fibroblast/gel contraction response to PDGF is probably related to other actin-dependent cellular responses to PDGF such as chemotaxis $(6,7)$ and vascular smooth muscle cell contraction (9). In fact, others $(30,31)$ have dissociated the chemotactic and mitogenic activi-

Table I. Stimulation of Fibroblast-driven Collagen Gel Contraction

\begin{tabular}{|c|c|c|c|}
\hline \multirow{2}{*}{$\begin{array}{l}\text { Experimental condition } \\
\text { (concentration) }\end{array}$} & \multicolumn{2}{|c|}{$\%$ Decrease in gel area } & \multirow[b]{2}{*}{ No. of replicates } \\
\hline & $4 \mathrm{~h}$ & $24 \mathrm{~h}$ & \\
\hline PDGF-AA $(30 n g / m l)$ & $1 \pm 1.0$ & $29 \pm 3.7$ & 9 \\
\hline PDGF-AB $(30 n g / m l)$ & $20 \pm 2.6$ & $65 \pm 2.7$ & 12 \\
\hline PDGF-BB $(30 n g / m l)$ & $14 \pm 2.8$ & $54 \pm 4.5$ & 12 \\
\hline TGF-beta $(10 \mathrm{ng} / \mathrm{ml})$ & $0 \pm 0$ & $15 \pm 2.0$ & 6 \\
\hline TGF-beta $(30 \mathrm{ng} / \mathrm{ml})$ & $0 \pm 0$ & $22 \pm 5.7$ & 6 \\
\hline $\mathrm{EGF}(10 n g / m l)$ & $2 \pm 0$ & $22 \pm 5.0$ & 15 \\
\hline $\mathrm{EGF}(30 \mathrm{ng} / \mathrm{ml})$ & $0 \pm 0$ & $25 \pm 5.0$ & 6 \\
\hline FGF $(10 n g / m l)$ & $0 \pm 0$ & $13 \pm 3.4$ & 9 \\
\hline FGF (30 ng/ml) & $0 \pm 0$ & $26 \pm 3.0$ & 6 \\
\hline $\operatorname{ADP}\left(10^{-6}-10^{-5} M\right)^{*}$ & $0 \pm 0$ & $21 \pm 1.5$ & 9 \\
\hline Adenosine $\left(10^{-6}-10^{-5} \mathrm{M}\right)$ & $0 \pm 0$ & $21 \pm 2.4$ & 9 \\
\hline Histamine $\left(10^{-7}-10^{-5} \mathrm{M}\right)$ & $0 \pm 0$ & $14 \pm 2.1$ & 27 \\
\hline Serotonin $\left(10^{-7}-10^{-5} \mathrm{M}\right)$ & $0 \pm 0$ & $0 \pm 0$ & 9 \\
\hline Medium alone & $0 \pm 0$ & $12 \pm 1.4$ & 81 \\
\hline
\end{tabular}

Mean \pm SEM.

* Since all concentrations listed stimulated little or no gel contraction, the data from each autacoid were pooled. 
ties of PDGF isolated from platelets. Furthermore, Nister et al. (32) have shown that fibroblast chemotaxis is stimulated by PDGF-BB but not -AA, whereas both isoforms stimulate fibroblast mitogenesis. Finally, it has recently been observed (Clark, F. C., and J. M. Folkvord, unpublished observations) by immunofluorescence microscopy using rhodamine-conjugated phalloidin toxin as a probe for fibrillar actin, that PDGF-BB and $-\mathrm{AB}$, but not $-\mathrm{AA}$, stimulate contraction of individual fibroblasts plated in glass chambers within a time frame similar to gel contraction. These differences observed between PDGF-AB/-BB and -AA activities in actin-dependent fibroblast responses and fibroblast mitogenesis are consistent with recent findings that multiple classes of PDGF receptors exist that have different binding specificities for the various PDGF isoforms $(21,32,33)$.

From our experiments on platelet releasates, it appears that PDGF is responsible for most, if not all, of the fibroblast/collagen gel contractile activity. Recently another platelet product, TGF-beta, has also been shown to stimulate fibroblastdriven collagen gel contraction (27). However, the contractile response to TGF-beta does not occur until 24-48 $\mathrm{h}$ after its addition (27, confirmed in this study). This delay allows sufficient time for TGF-beta to induce de novo synthesis of PDGF, a well-documented response of fibroblasts to TGF-beta (24). In contrast to the delayed time course of contraction seen with TGF-beta, platelet releasates and PDGF stimulated contraction by $2-5 \mathrm{~h}$ after addition (Figs. 1 and $2 A$ ). The difference in time course coupled with the well-known fact that TGF-beta is released from platelets in a stable, latent form, whether in vitro or in vivo during blood coagulation (25), make TGF-beta a highly unlikely candidate for the gel-contracting activity found in platelet releasates.

PDGF may promote tissue repair through at least two distinct processes with either beneficial or detrimental outcomes. First, it is well established that PDGF stimulates fibroblast and smooth muscle cell expansion (8) and migration $(6,7)$. Such mesenchymal cell ingrowth in vivo can be beneficial due to the repopulation of a space created by tissue loss. On the other hand, mesenchymal cell ingrowth can be detrimental because of invasion of a physiologically functional space (e.g., encroachment of a smooth muscle-rich atheromatous plaque into a blood vessel lumen, or invasion of fibroblasts into respiratory airways and lung alveoli after pulmonary injury). Second, PDGF stimulates fibroblast-driven contraction of collagen gel matrix as demonstrated in this report. Tissue contraction can be beneficial vis a vis reducing the amount of fibroplasia and angiogenesis needed to reestablish organ integrity after tissue loss. On the other hand, tissue contraction can be detrimental vis a vis reduction of physiologically functional space (e.g., joint contracture, bowel obstruction, esophageal constriction, pulmonary fibrosis, constrictive pericarditis/ myocarditis). Through future studies we hope to determine whether PDGF is responsible for stimulating tissue contraction in these various situations and what modulatory mechanisms exist for such activity. A better understanding of nonmuscle tissue contraction may allow appropriate intervention in wound repair and fibrocontractive disorders.

\section{Acknowledgments}

We thank Dr. P. M. Henson and Dr. M. G. Tonnesen for reviewing the manuscript, and P. Hammond for typing the manuscript.
This work was supported by National Institutes of Health grants AM-31514 and HL-27353, the Scleroderma Foundation, and the Lester I. Conrad Foundation.

\section{References}

1. Clark, R. A. F. 1988. Overview and general consideration of wound repair. In Molecular and Cellular Biology of Wound Repair. R. A. F. Clark and P. M. Henson, editors. Plenum Press, New York. 3-33.

2. Skalli, O., and G. Gabbiani. 1988. The biology of the myofibroblast relationship to wound contraction and fibrocontractive disorders. In Molecular and Cellular Biology of Wound Repair. R. A. F. Clark and P. M. Henson, editors. Plenum Press, New York. 373-402.

3. Gabbiani, G., B. J. Hirschel, G. B. Ryan, P. R. Statkov, and G. Majno. 1972. Granulation tissue as a contractile organ. A study of structure and function. J. Exp. Med. 135:719-734.

4. Gabbiani, G., C. Chapponnier, and I. Huttner. 1978. Cytoplasmic filaments and gap junctions in epithelial cells and myofibroblast during wound healing. J. Cell Biol. 76:561-568.

5. Singer I. I., D. W. Kawka, D. M. Kazazis, and R. A. F. Clark. 1984. In vivo co-distribution of fibronectin and actin fibers in granulation tissue. Immunofluorescence and electron microscope studies of the fibronexus at the myofibroblast surface. J. Cell Biol. 98:20912106.

6. Seppa H. E. J., G. R. Grotendorst, S. I. Seppa, E. Schiffmann, and G. R. Martin. 1982. Platelet-derived growth factor is chemotactic for fibroblasts. J. Cell Biol. 92:584-588.

7. Senior, R. M., G. L. Griffin, J. S. Huang, D. A. Walz, and T. F. Deuel. 1983. Chemotactic activity of platelet alpha granule proteins for fibroblasts. J. Cell Biol. 96:382-385.

8. Ross, R., E. W. Raines, and D. F. Bowen-Pope. 1986. The biology of platelet-derived growth factor. Cell. 45:155-169.

9. Berk, B. C., R. W. Alexander, T. A. Brock, M. A. Gimbrone, Jr., and C. Webb. 1986. Vasoconstriction: a new activity for platelet derived growth factor. Science (Wash. DC). 232:87-90.

10. Bell, E., B. Ivarsson, and C. Merrill. 1979. Production of a tissue-like structure by contraction of collagen lattices by human fibroblasts of different proliferative potential in vitro. Proc. Natl. Acad. Sci (USA). 76:1274-1278.

11. Singer I. I. 1979. The fibronexus: a transmembrane association of fibronectin-containing fibers and bundles of $5 \mathrm{~nm}$ filaments in hamster and human fibroblasts. Cell. 16:675-685.

12. Hynes, R. O., and A. T. Destree. 1978. Relationships between fibronectin (LETS protein) and actin. Cell. 15:875-886.

13. Bell, E., H. P. Ehrlich, D. J. Buttle, and T. Nakatsuji. 1981. Living tissue formed in vitro and accepted as skin-equivalent tissue of full thickness. Science (Wash. DC). 211:1052-1054.

14. McPherson, J. M., D. G. Wallace, S. J. Sawamura, A. Conti, R. A. Condell, S. Wade, and K. A. Piez. 1985. Collagen fibrillogenesis in vitro: a characterization of fibril quality as a function of assembly conditions. Collagen Relat. Res. 5:119-135.

15. Steinberg, B. M., K. Smith, M. Colozzo, and R. Pollack. 1980. Establishment and transformation diminish the ability of fibroblasts to contract a native collagen gel. J. Cell Biol. 87:304-308.

16. Eisen, A. Z., A. P. Pentland, E. A. Bauer, and G. I. Goldberg. 1987. Behavior of epidermolysis bullosa fibroblasts in a hydrated collagen lattice. J. Invest. Dermatol. 88:741-746.

17. Lebarca, C., and K. Paigen. 1980. A simple, rapid, and sensitize DNA assay procedure. Anal. Biochem. 102:344-352.

18. Kelly, J. D., E. W. Raines, R. Ross, and M. J. Murray. 1985. The beta chain of PDGF alone is sufficient for mitogenesis. EMBO (Eur. Mol. Biol. Organ.) J. 4:3399-3405.

19. Raines, E. W., S. K. Dower, and R. Ross. 1989. Interleukin-1 mitogenic activity for fibroblasts and smooth muscle cells is due to PDGF-AA. Science (Wash. DC). 243:393-396.

20. McPherson, J. M., H. Sage, and P. Bornstein. 1981. Isolation and characterization of a glycoprotein secreted by aortic endothelial 
cells in culture: apparent identity with platelet thrombospondin. $J$. Biol. Chem. 256:11330-11336.

21. Lowry, O. H., N. J. Rosebrough, A. L. Farr, and R. J. Randall. 1951. Protein measurement with the Folin phenol reagent. J. Biol. Chem. 193:265-275.

22. Hart, C. E., J. W. Forstrom, J. D. Kelly, R. A. Siefert, R. A. Smith, R. Ross, M. J. Murray, and D. F. Bowen-Pope. 1988. Two classes of PDGF receptors recognize different isoforms of PDGF. Science (Wash. DC). 240:1529-1531.

23. Bowen-Pope, D. F., and R. Ross. 1982. Platelet-derived growth factor. II. Specific binding to cultured cells. J. Biol. Chem. 257:51615171.

24. Loef, E. B., J. A. Proper, A. S. Goustin, G. D. Shipley, P. E. DeCorleto, and H. L. Moses. 1986. Induction of c-sis mRNA and activity similar to platelet-derived growth factor by transforming growth factor beta. Proc. Natl. Acad. Sci. USA. 83:2453-2457.

25. Sporn, M. B., A. B. Roberts, L. M. Wakefield, and B. deCrombrugghe. 1987. Some recent advances in the chemistry and biology of transforming growth factor-beta. J. Cell Biol. 105:1039-1045.

26. Shipley, G. D., P. W. Cook, M. R. Pittlekow, and R. J. Coffey, Jr. 1989. Response to and production of aFGF, bFGF and TGF- by cultured normal human skin cells. J. Cell. Biochem. 13B:143.

27. Montesano, R., and L. Orci. 1988. Transforming growth factor beta stimulates collagen-matrix contraction by fibroblasts: implications for wound healing. Proc. Natl. Acad. Sci. USA. 85:4894-4897.
28. Seyedin, S. M., A. Y. Thompson, H. Bentz, D. M. Rosen, J. M. McPherson, A. Conti, N. R. Siegel, G. R. Galluppi, and K. A. Piez. 1986. Cartilage-inducing factor-A: apparent identity to transforming growth factor-beta. J. Biol. Chem. 261:5693-5695.

29. Sato, Y., and D. B. Rifkin. 1988. Autocrine activities of basic fibroblast growth factor. Regulation of endothelial cell movement, plasminogen activator synthesis, and DNA synthesis. J. Cell Biol. 107:1199-1206.

30. Williams, L. T., H. N. Antoniades, and E. J. Goetzl. 1983. Platelet-derived growth factor stimulates mouse 3T3 cell mitogenesis and leukocyte chemotaxis through different structural determinants. $J$. Clin. Invest. 72:1759-1763.

31. Senior, R. M., J. S. Huang, G. L. Griffin, and T. F. Deuel. 1985. Dissociation of chemotactic and mitogenic activites of platelet-derived growth factor by human neutrophil elastase. J. Cell Biol. 100:351-356.

32. Nister, M., A. Hammacher, K. Mellstrom, A. Siegbahn, L. Ronnstrand, B. Westermark, and C.-H. Heldin. 1988. A glioma-derived PDGF A chain homodimer has different functional activities from a PDGF AB heterodimer purified from human platelets. Cell. 52:791-799.

33. Heldin, C.-H., G. Backstrom, A. Ostman, A. Hammacher, L. Ronnstrand, K. Rubin, M. Nister, and B. Westermark. 1988. Binding of different dimeric forms of PDGF to human fibroblasts: evidence for two separate receptor types. EMBO (Eur. Mol. Biol. Organ.) J. 7:1387-1393. 